\title{
Pengaruh Pemberian Kombinasi Jenis dan Dosis Pupuk Kandang terhadap pH, N-Total, Serapan-N, serta Hasil Tanaman Pakchoi (Brassica chinensis L.) pada Fluventic Eutrudepts
}

\author{
Dewi Septian Pujiningsih, Anni Yuniarti*, dan Apong Sandrawati \\ Departemen Ilmu Tanah dan Sumber Daya Lahan, Fakultas Pertanian, Universitas Padjadjaran \\ Jl. Raya Bandung-Sumedang KM 21 Jatinangor Indonesia 45363 \\ *Alamat korespondensi: anni_yuniarti@yahoo.com
}

\begin{abstract}
The effect of the combination types and dosages of manure on soil reaction, $\mathrm{N}$-total, $\mathrm{N}$-uptake, and yield of pakchoi (Brassica chinensis L.) on fluventics eutrudepts
\end{abstract}

This research was conducted to determine the effect of the combination types and dosages of manure on soil reaction, $\mathrm{N}$-total, $\mathrm{N}$-uptake, and yield of pakchoi (Brassica chinensis L.) on Fluventics Eutrudepts. The study was conducted from April to Agustus 2010 in the research station Greenhouse Faculty of Agriculture, Universitas Padjadjaran, Jatinangor Sumedang, West Java, elevated at 700 meters above sea level. The experimental design used was Randomized Block Design (RBD) with eleven treatments and three replications, consisted of without fertilizer (control); one dose of inorganic fertilizer and chicken manure $25 \mathrm{~g} /$ polybag; 0.75 dose of inorganic fertilizer and chicken manure $37.5 \mathrm{~g} /$ polybag; 0.5 dose of inorganic fertilizer and chicken manure $50 \mathrm{~g} /$ polybag; 0.25 dose of inorganic fertilizer and chicken manure $62.5 \mathrm{~g} /$ polybag; no inorganic fertilizer and chicken manure $75 \mathrm{~g}$ /polybag; one dose of inorganic fertilizer and sheep manure 25 g/polybag; 0.75 dose of inorganic fertilizer and sheep manure $37.5 \mathrm{~g} /$ polybag; 0.5 dose of inorganic fertilizer and sheep manure $50 \mathrm{~g} /$ polybag; 0.25 dose of inorganic fertilizer and sheep manure 62.5 g/polybag; no inorganic fertilizer and sheep manure $75 \mathrm{~g} /$ polybag. The results showed that significant effects of soil reaction, $\mathrm{N}$-total, $\mathrm{N}$-uptake, and yield of pakchoi from combination of types and dosages of manure. Treatment of 0.25 dose of inorganic fertilizer and chicken manure $62.5 \mathrm{~g} /$ polybag increased yields of pakchoi became $76.77 \mathrm{~g}$.

Keywords: Manure combination, Pakchoi, Fluventics Eutrudepts

\begin{abstract}
ABSTRAK
Percobaan ini dilakukan untuk mengetahui pengaruh pemberian kombinasi jenis dan dosis pupuk kandang terhadap $\mathrm{pH}$ tanah, $\mathrm{N}$-total, serapan-N, dan hasil tanaman pakchoi (Brassica chinensis $\mathrm{L}$.) pada Fluventics Eutrudepts. Percobaan ini dilaksanakan pada bulan April sampai dengan Agustus 2010 di Rumah kaca kebun Percobaan Fakultas Pertanian Universitas Padjadjaran, Jatinangor, Kabupaten Sumedang, Jawa Barat, dengan ketinggian tempat 700 meter di atas permukaan laut. Rancangan percobaan yang digunakan adalah Rancangan Acak Kelompok (RAK) faktor tunggal dengan sebelas perlakuan dan tiga ulangan, yaitu yang terdiri dari tanpa pupuk (Kontrol); 1 dosis pupuk anorganik dan Pupuk kandang ayam 25 g/polibeg; 0,75 dosis pupuk anorganik dan Pupuk kandang ayam 37,5 g/polibeg; 0,5 dosis pupuk anorganik dan Pupuk kandang ayam 50 g/polibeg; 0,25 dosis pupuk anorganik dan Pupuk kandang ayam 62,5 g/polibeg; tanpa pupuk anorganik dan pupuk kandang ayam $75 \mathrm{~g} /$ polibeg; 1 dosis pupuk anorganik dan pupuk kandang domba 25 g/polibeg; 0,75 dosis pupuk anorganik dan Pupuk kandang domba 37,5 g/polibeg; 0,5 dosis pupuk anorganik dan pupuk kandang domba $50 \mathrm{~g} /$ polibeg; 0,25 dosis pupuk anorganik dan pupuk kandang domba 62,5 g/polibeg; dan tanpa pupuk anorganik dan pupuk kandang domba $75 \mathrm{~g} /$ polibeg. Hasil penelitian menunjukkan terdapat pengaruh terhadap $\mathrm{pH}, \mathrm{N}$-total, serapan $\mathrm{N}$, dan hasil tanaman pakchoi akibat pemberian kombinasi jenis dan dosis pupuk kandang. Perlakuan 0,25 dosis pupuk
\end{abstract}


anorganik dan pupuk kandang ayam 62,5 g/polibeg dapat meningkatkan hasil tanaman pakchoi menjadi $76,77 \mathrm{~g}$.

Kata Kunci: Kombinasi pupuk kandang, pakchoi, Fluventics Eutrudepts

\section{PENDAHULUAN}

Produk pertanian yang sehat dan bernilai gizi tinggi dapat diproduksi dengan metode yang dikenal dengan pertanian organik (Badan Penelitian dan Pengembangan Pertanian, 2002). Permintaan produk pertanian organik dunia cenderung meningkat 20\%, terutama sayuran dan buah-buahan organik. Perkembangan ini didorong oleh dukungan kebijakan pemerintah, dukungan pasar modern menyerap $50 \%$ produk organik, dan harga yang tinggi ditingkat konsumen (Balai Penelitian Tanah, 2005). Pupuk organik merupakan pupuk yang terbuat dari bahan-bahan alami yang berasal dari dekomposisi sisa-sisa tanaman, fosil hewan, dan kandang hewan yang dirombak menjadi unsur hara tersedia bagi tanaman (Hardjowigeno, 2007; Syafruddin dkk., 2012).

Pupuk organik merupakan sumber nitrogen $(\mathrm{N})$ yang utama, serta berperan dalam memperbaiki sifat fisik, kimia, biologi tanah dan juga lingkungan, serta memiliki unsur hara makro $(\mathrm{N}, \mathrm{P}, \mathrm{K}, \mathrm{S}, \mathrm{Ca}$, $\mathrm{Mg}$,) dan unsur hara mikro (Fe, Mn, $\mathrm{Cu}, \mathrm{Zn}, \mathrm{B}, \mathrm{Co}$, dan Mo) yang dibutuhkan tanaman (Napitupulu \& Wiranto, 2010; Sarief, 1989). Salah satu ciri dari pupuk organik adalah kandungan unsur haranya rendah, sehingga pemakaiannya untuk tanaman harus dalam jumlah yang banyak (Balai Penelitian Tanah, 2005). Pupuk kandang merupakan pupuk organik yang berasal dari kandang hewan baik berbentuk padat (feses) maupun cair (urine), sisa-sisa makanan yang tidak dapat dihabiskan, dan alas kandang yang bercampur menjadi satu (Sarief, 1989). Penggunaan pupuk kandang tidak perlu kita ragukan lagi kemampuannya menjamin kesuburan tanah berkelanjutan (Atmojo, 2007). Penggunaan pupuk kandang pada berbagai ordo tanah, sampai saat ini tidak ada standar dosis tertentu, tetapi kebanyakan petani menggunakan dosis sekitar 10$20 \mathrm{t} / \mathrm{ha}$ untuk tanaman sayuran Indonesia (Musnamar, 2003).

Pakchoi (Brassica chinensis L.) merupakan sayuran daun yang disukai banyak orang dan bernilai ekonomi tinggi. Produksi nasional pakchoi di Indonesia saat ini mencapai 565,636 ton (Departemen Pertanian, 2009). Dosis pupuk anorganik (N, P, K) yang direkomendasikan untuk tanaman pakchoi, yaitu Urea $(46 \%$ N) $100 \mathrm{~kg} / \mathrm{ha}$, SP$36\left(36 \% \mathrm{P}_{2} \mathrm{O} 5\right) 150 \mathrm{~kg} / \mathrm{ha}, \mathrm{KCl}\left(60 \% \mathrm{~K}_{2} \mathrm{O}\right) 75 \mathrm{~kg} / \mathrm{ha}$, dan pupuk kandang $15 \mathrm{t} / \mathrm{ha}$ (Wahyudi, 2010).

Fluventic Eutrudepts di Jatinangor termasuk ke dalam sub ordo Inceptisols (Sudirja dkk., 2007). Tanah ini merupakan tanah muda, tetapi lebih berkembang dari pada Entisol (Soepardi,1983). Inceptisols merupakan salah satu ordo tanah yang memiliki potensi yang cukup baik untuk lahan pertanian, namun pada umumnya Inceptisols memiliki tingkat kesuburan yang rendah sampai sedang dan ketersediaan unsur N, P, K yang rendah pula. Salah satu sub grup Inceptisols yang memiliki kesuburan tanah yang rendah adalah Fluventic Eutrudepts. Hal ini ditunjukkan oleh $\mathrm{pH}$ tanah yang agak masam $(5,7), \mathrm{N}$-total rendah $(0,1 \%)$, P-tersedia sedang $(10,3 \mathrm{mg} / \mathrm{kg})$, K-potensial rendah $(11,1 \mathrm{mg} / 100 \mathrm{~g})$.

Pupuk kandang ayam dan domba masingmasing mempunyai kandungan kimia yang berbeda, oleh karena itu memiliki respon yang berbeda juga terhadap pertumbuhan tanaman. Pupuk kandang ayam dan pupuk kandang domba mengandung bahan organik yang tinggi. Penambahan pupuk tersebut ke dalam tanah akan mengalami oksidasi enzimatik yaitu $\mathrm{CO}_{2}, \mathrm{H}_{2} \mathrm{O}, \mathrm{NH}_{4}^{+}, \mathrm{NO}_{3}^{-}, \mathrm{H}_{2} \mathrm{PO}_{4}^{-}$, $\mathrm{SO}_{4}{ }^{2-}$ dan energi sebagai hasil utama. Oksidasi bahan organik dapat dituliskan sebagai berikut (Hakim, 1986):

$$
(\mathrm{C}, 4 \mathrm{H})+2 \mathrm{O}_{2} \rightarrow \quad \begin{gathered}
\text { oksidasi } \\
\mathrm{CO}_{2}+2 \mathrm{H}_{2} \mathrm{O}+\text { Energi }
\end{gathered}
$$

Berdasarkan uraian di atas, pemberian pupuk kandang ayam, pupuk kandang domba, dan pupuk anorganik urea $(45 \% \mathrm{~N}), \mathrm{SP}-36\left(36 \% \mathrm{P}_{2} \mathrm{O}_{5}\right)$, serta $\mathrm{KCl}\left(60 \% \mathrm{~K}_{2} \mathrm{O}\right)$ pada pakchoi dengan dosis yang berbeda akan memberikan pengaruh berbeda sesuai dengan dosis dan perlakuan yang diberikan, tetapi kombinasi dosis dan jenis pupuk kandang yang mana yang memberikan pengaruh terbaik bagi pertumbuhan hasil pakchoi belum diketahui. Peningkatan dosis pupuk kandang ayam dan domba diharapkan akan memperbaiki sifat fisik dan kimia tanah termasuk peningkatan $\mathrm{pH}, \mathrm{N}$-total, serapan- $\mathrm{N}$, dan meningkatkan kuantitas dan kualitas hasil tanaman pakchoi. 


\section{BAHAN DAN METODE}

Penelitian ini dilaksanakan pada bulan April sampai dengan Juni 2010 di rumah kaca Kebun Percobaan Fakultas Pertanian Universitas Padjadjaran dengan ketinggian tempat $\pm 700 \mathrm{~m} \mathrm{dpl}$, sedangkan analisis tanah dan tanaman dilaksanakan bulan Juli sampai dengan Agustus 2010. Analisis sifat kimia tanah dilakukan di Laboratorium Kesuburan Tanah dan Nutrisi Tanaman Fakultas Pertanian Universitas Padjadjaran Jatinangor Kabupaten Sumedang, Jawa Barat. Penelitian menggunakan Rancangan Acak Kelompok (RAK) faktor tunggal, terdiri dari 11 perlakuan dengan tiga kali ulangan, sehingga seluruhnya berjumlah 33 polibeg percobaan. Perlakuan terdiri atas sebelas perlakuan yaitu:

A = Tanpa pupuk (Kontrol)

$\mathrm{B}=1$ dosis pupuk anorganik + Pukan ayam 25 $\mathrm{g} /$ polibeg setara $10 \mathrm{t} / \mathrm{ha}$

$\mathrm{C}=0,75$ dosis pupuk anorganik + Pukan ayam 37,5 $\mathrm{g} /$ polibeg setara $15 \mathrm{t} / \mathrm{ha}$

$\mathrm{D}=0,5$ dosis pupuk anorganik + Pukan ayam 50 $\mathrm{g} /$ polibeg setara $20 \mathrm{t} / \mathrm{ha}$

$\mathrm{E}=0,25$ dosis pupuk anorganik + Pukan ayam 62,5 $\mathrm{g} /$ polibeg setara $\mathrm{t} / \mathrm{ha}$

$\mathrm{F}=$ Tanpa pupuk anorganik + Pukan ayam 75 $\mathrm{g} /$ polibeg setara $30 \mathrm{t} / \mathrm{ha}$

$\mathrm{G}=1$ dosis pupuk anorganik + Pukan domba 25 $\mathrm{g} /$ polibeg setara $10 \mathrm{t} / \mathrm{ha}$
$\mathrm{H}=0,75$ dosis pupuk anorganik+Pukan domba 37,5 $\mathrm{g} /$ polibeg setara $15 \mathrm{t} / \mathrm{ha}$

$\mathrm{I}=0,5$ dosis pupuk anorganik + Pukan domba 50 $\mathrm{g} /$ polibeg setara $20 \mathrm{t} / \mathrm{ha}$

$\mathrm{J}=0,25$ dosis pupuk anorganik + Pukan domba 62,5 $\mathrm{g} /$ polibeg setara $25 \mathrm{t} / \mathrm{ha}$

$\mathrm{K}$ = Tanpa pupuk anorganik + Pukan domba 75 $\mathrm{g} /$ polibeg setara $30 \mathrm{t} / \mathrm{ha}$

\section{HASIL DAN PEMBAHASAN}

Hasil analisis statistik menunjukkan bahwa pemberian kombinasi jenis dan dosis pupuk kandang tidak berpengaruh nyata antar tiap perlakuan terhadap $\mathrm{pH}$ (Tabel 1). Hal ini disebabkan semakin tinggi dosis pupuk kandang ayam dan domba yang diberikan, maka gugus fenol yang dilepaskan semakin tinggi. Penambahan bahan organik dapat memicu dekomposisi oleh mikroba menghasilkan $\mathrm{OH}^{-}$yang meningkatkan $\mathrm{pH} \mathrm{H}_{2} \mathrm{O}$ (Pavlou 2007; Syukur, 2008). Pengaruh penambahan bahan organik terhadap $\mathrm{pH}$ tanah dapat meningkatkan atau menurunkan tergantung oleh tingkat kematangan bahan organik yang belum matang atau bahan organik yang masih mengalami proses dekomposisi, biasanya akan menyebabkan penurunan $\mathrm{pH}$ tanah, karena asam-asam organik hasil dekomposisi akan melepaskan asam-asam organik (asam humat dan asam fulvat) yang menyebabkan penurunan $\mathrm{pH}$ tanah.

Tabel 1. Pengaruh kombinasi jenis dan dosis pupuk kandang pada Fluventic Eutrudepts terhadap pH tanah

\begin{tabular}{lc}
\hline \multicolumn{1}{c}{ Perlakuan } & $\mathrm{pH}$ \\
\hline $\mathrm{A}=$ Tanpa pupuk (Kontrol) & $5,97 \mathrm{a}$ \\
$\mathrm{B}=1$ dosis pupuk anorganik + Pukan ayam $25 \mathrm{~g} /$ polibeg & $6,05 \mathrm{ab}$ \\
$\mathrm{C}=0,75$ dosis pupuk anorganik + Pukan ayam 37,5 g/polibeg & $6,05 \mathrm{ab}$ \\
$\mathrm{D}=0,5$ dosis pupuk anorganik + Pukan ayam 50 g/polibeg & $6,06 \mathrm{ab}$ \\
$\mathrm{E}=0,25$ dosis pupuk anorganik + Pukan ayam 62,5 g/polibeg & $6,06 \mathrm{ab}$ \\
$\mathrm{F}=$ Tanpa pupuk anorganik + Pukan ayam 75 g/polibeg & $6,08 \mathrm{ab}$ \\
$\mathrm{G}=1$ dosis pupuk anorganik + Pukan domba $25 \mathrm{~g} /$ polibeg & $6,12 \mathrm{ab}$ \\
$\mathrm{H}=0,75$ dosis pupuk anorganik + Pukan domba 37,5 g/polibeg & $6,12 \mathrm{ab}$ \\
$\mathrm{I}=0,5$ dosis pupuk anorganik + Pukan domba 50 g/polibeg & $6,15 \mathrm{ab}$ \\
$\mathrm{J}=0,25$ dosis pupuk anorganik + Pukan domba 62,5 g/polibeg & $6,18 \mathrm{~b}$ \\
$\mathrm{~K}=$ Tanpa pupuk anorganik + Pukan domba 75 g/polibeg & $6,23 \mathrm{~b}$ \\
\hline Keterangan: Angka-angka yang diikuti huruf yang sama tidak berbeda nyata menurut uji jarak berganda Duncan 5\%
\end{tabular}

Keterangan: Angka-angka yang diikuti huruf yang sama tidak berbeda nyata menurut uji jarak berganda Duncan $5 \%$

Berdasarkan hasil analisis statistik yang telah dilakukan menunjukkan bahwa pemberian kombinasi jenis dan dosis pupuk kandang tidak memberikan pengaruh nyata terhadap nilai $\mathrm{N}$-total (Tabel 2). Namun pengaruh nyata tersebut hanya terlihat pada perlakuan dosis 0,25 dosis pupuk anorganik + pupuk kandang ayam 62,5 g/polibeg, jika dibandingkan dengan kontrol dan perlakuan yang lainnya. 
Tabel 2. Pengaruh kombinasi jenis dan dosis pupuk kandang pada Fluventic Eutrudepts terhadap N-total

\begin{tabular}{lc}
\hline \multicolumn{1}{c}{ Perlakuan } & N-Total (\%) \\
\hline $\mathrm{A}=$ Tanpa pupuk (Kontrol) & $0,19 \mathrm{a}$ \\
$\mathrm{B}=1$ dosis pupuk anorganik + Pukan ayam $25 \mathrm{~g} /$ polibeg & $0,27 \mathrm{~b}$ \\
$\mathrm{C}=0,75$ dosis pupuk anorganik + Pukan ayam 37,5 g/polibeg & $0,26 \mathrm{~b}$ \\
$\mathrm{D}=0,5$ dosis pupuk anorganik + Pukan ayam $50 \mathrm{~g} /$ polibeg & $0,23 \mathrm{ab}$ \\
$\mathrm{E}=0,25$ dosis pupuk anorganik + Pukan ayam 62,5 g/polibeg & $0,29 \mathrm{c}$ \\
$\mathrm{F}=$ Tanpa pupuk anorganik + Pukan ayam 75 g/polibeg & $0,24 \mathrm{ab}$ \\
$\mathrm{G}=1$ dosis pupuk anorganik + Pukan domba 25 g/polibeg & $00,24 \mathrm{ab}$ \\
$\mathrm{H}=0,75$ dosis pupuk anorganik + Pukan domba 37,5 g/polibeg & $00,24 \mathrm{ab}$ \\
$\mathrm{I}=0,5$ dosis pupuk anorganik + Pukan domba $50 \mathrm{~g} /$ polibeg & $00,23 \mathrm{ab}$ \\
$\mathrm{J}=0,25$ dosis pupuk anorganik + Pukan domba 62,5 g/polibeg & $00,24 \mathrm{ab}$ \\
$\mathrm{K}=$ Tanpa pupuk anorganik + Pukan domba 75 g/polibeg & $00,24 \mathrm{ab}$ \\
\hline Keterangan: Angka-angka yang diikuti huruf yang sama tidak berbeda nyata menurut uji jarak berganda Duncan 5\%
\end{tabular}

Setiap peningkatan dosis pupuk $\mathrm{N}$, baik berasal dari pupuk anorganik maupun organik, meningkatkan kandungan $\mathrm{N}$-total di dalam tanah. Hal ini dikarenakan peningkatan dosis pupuk organik akan menyebabkan peningkatan aktivitas dari mikroorganisme, sehingga dengan demikian semakin banyak $\mathrm{N}$-organik yang termineralisasi. Pupuk $\mathrm{N}$ dalam bentuk urea $\left(\mathrm{CO}\left[\mathrm{NH}_{2}\right]_{2}\right)$ di dalam tanah dihidrolisis oleh enzim Nitrogenase yang menghasilkan $\mathrm{NH}_{4}{ }^{+}$dan $\mathrm{NO}_{3}{ }^{-}$(Tisdale et al., 1993), sehingga ketersediaan $\mathrm{N}$ dalam tanah meningkat.

Berdasarkan hasil analisis statistik bahwa pemberian kombinasi jenis dan dosis pupuk kandang yang menunjukkan serapan- $\mathrm{N}$ terbaik terdapat pada perlakuan 0,25 dosis pupuk anorganik dan pupuk kandang ayam 62,5 g/polibeg, namun tidak menunjukkan pengaruh yang nyata pada tiap perlakuan, kecuali jika dibandingkan dengan kontrol dan perlakuan dosis pupuk kandang domba $30 \mathrm{t} / \mathrm{ha}$ (Tabel 3). Makin tingginya efektifitas pemupukan $\mathrm{N}$ berarti semakin tinggi unsur $\mathrm{N}$ yang tersedia bagi tanaman atau makin rendah $\mathrm{N}$ yang hilang melalui penguapan dan pencucian (Winarso, 2005). Keefektifan pupuk dengan meningkatkan dosis pupuk kandang hingga $10 \mathrm{t} / \mathrm{ha}$ dapat menurunkan jumlah $\mathrm{N}$ yang dibutuhkan tanaman untuk produksi (Sutejo, 2002).

Tabel 3. Pengaruh kombinasi jenis dan dosis pupuk kandang pada Fluventic Eutrudepts terhadap serapan-N

\begin{tabular}{lc}
\hline \multicolumn{1}{c}{ Perlakuan } & Serapan-N (g/tanaman) \\
\hline $\mathrm{A}=$ Tanpa pupuk (Kontrol) & $2,90 \mathrm{a}$ \\
$\mathrm{B}=1$ dosis pupuk anorganik + Pukan ayam $25 \mathrm{~g} /$ polibeg & $28,66 \mathrm{bc}$ \\
$\mathrm{C}=0,75$ dosis pupuk anorganik + Pukan ayam 37,5 g/polibeg & $33,77 \mathrm{bc}$ \\
$\mathrm{D}=0,5$ dosis pupuk anorganik + Pukan ayam $50 \mathrm{~g} /$ polibeg & $28,26 \mathrm{bc}$ \\
$\mathrm{E}=0,25$ dosis pupuk anorganik + Pukan ayam 62,5 g/polibeg & $38,98 \mathrm{c}$ \\
$\mathrm{F}=$ Tanpa pupuk anorganik + Pukan ayam 75 g/polibeg & $28,50 \mathrm{bc}$ \\
$\mathrm{G}=1$ dosis pupuk anorganik + Pukan domba 25 g/polibeg & $36,13 \mathrm{bc}$ \\
$\mathrm{H}=0,75$ dosis pupuk anorganik + Pukan domba 37,5 g/polibeg & $31,28 \mathrm{bc}$ \\
$\mathrm{I}=0,5$ dosis pupuk anorganik + Pukan domba 50 g/polibeg & $25,02 \mathrm{bc}$ \\
$\mathrm{J}=0,25$ dosis pupuk anorganik + Pukan domba 62,5 g/polibeg & $21,34 \mathrm{bc}$ \\
$\mathrm{K}=$ Tanpa pupuk anorganik + Pukan domba 75 g/polibeg & $14,53 \mathrm{~b}$ \\
\hline
\end{tabular}

Keterangan: Angka-angka yang diikuti huruf yang sama tidak berbeda nyata menurut uji jarak berganda Duncan 5\%

Berdasarkan hasil uji statistik yang telah dilakukan, bahwa pengaruh pemberian kombinasi jenis dan dosis pupuk kandang yang menunjukkan hasil tertinggi terhadap hasil tanaman pakchoi terdapat pada perlakuan 0,25 dosis pupuk anorganik dan pupuk kandang ayam $62,5 \mathrm{~g}$ polibeg $\mathrm{t} / \mathrm{ha}$. Namun hal ini tidak berbeda nyata terhadap masing- masing perlakuan, kecuali jika dibandingkan dengan perlakuan kontrol dan perlakuan dosis pupuk kandang domba 75 g/polibeg, meskipun pada pengamatan penunjang tinggi tanaman dan jumlah daun tertinggi tidak terdapat pada perlakuan 0,25 dosis pupuk anorganik dan pupuk kandang ayam 62,5 g/polibeg (Tabel 4). 
Tabel 4. Pengaruh kombinasi jenis dan dosis pupuk kandang pada Fluventic Eutrudepts terhadap hasil tanaman pakchoi

\begin{tabular}{lc}
\hline \multicolumn{1}{c}{ Perlakuan } & Hasil (g/tanaman) \\
\hline $\mathrm{A}=$ Tanpa pupuk (Kontrol) & $8,83 \mathrm{a}$ \\
$\mathrm{B}=1$ dosis pupuk anorganik + Pukan ayam $25 \mathrm{~g} /$ polibeg & $62,33 \mathrm{bc}$ \\
$\mathrm{C}=0,75$ dosis pupuk anorganik + Pukan ayam 37,5 g/polibeg & $51,87 \mathrm{bc}$ \\
$\mathrm{D}=0,5$ dosis pupuk anorganik + Pukan ayam 50 g/polibeg & $5670 \mathrm{bc}$ \\
$\mathrm{E}=0,25$ dosis pupuk anorganik + Pukan ayam 62,5 g/polibeg & $76,77 \mathrm{c}$ \\
$\mathrm{F}=$ Tanpa pupuk anorganik + Pukan ayam $75 \mathrm{~g} /$ polibeg & $67,13 \mathrm{bc}$ \\
$\mathrm{G}=1$ dosis pupuk anorganik + Pukan domba $25 \mathrm{~g} /$ polibeg & $58,80 \mathrm{bc}$ \\
$\mathrm{H}=0,75$ dosis pupuk anorganik + Pukan domba 37,5 g/polibeg & $64,53 \mathrm{bc}$ \\
$\mathrm{I}=0,5$ dosis pupuk anorganik + Pukan domba 50 g/polibeg & $47,07 \mathrm{bc}$ \\
$\mathrm{J}=0,25$ dosis pupuk anorganik + Pukan domba 62,5 g/polibeg & $51,20 \mathrm{bc}$ \\
$\mathrm{K}=$ Tanpa pupuk anorganik + Pukan domba $75 \mathrm{~g} /$ polibeg & $29,53 \mathrm{ab}$ \\
\hline Keterangan: Angka-angka yang diikuti huruf yang sama tidak berbeda nyata menurut uji jarak berganda Duncan $5 \%$
\end{tabular}

Pemberian kombinasi jenis dan dosis pupuk anorganik dan macam pupuk kandang pada semua taraf memberikan pengaruh nyata terhadap hasil pakchoi dibandingkan dengan kontrol, kecuali pada perlakuan dosis pupuk kandang domba $30 \mathrm{t} / \mathrm{ha}$. Hal ini dikarenakan pupuk kandang domba yang memiliki nilai $\mathrm{C} / \mathrm{N}$ sebesar 17 serta memiliki tekstur yang khas, sehingga memerlukan waktu yang lama dalam proses dekomposisinya, selain itu kandungan unsur hara yang terdapat pada pupuk kandang domba lebih rendah jika dibandingkan dengan pupuk kandang ayam, dan diduga penggunaannya akan lebih efektif jika dikombinasikan dengan penggunaan pupuk anorganik, agar unsur haranya bisa lebih tersedia untuk tanaman.

Fluventic Eutrudepts yang digunakan dalam percobaan ini memiliki tingkat kesuburan tanah yang tergolong rendah sehingga tidak mampu memasok unsur hara yang dibutuhkan oleh tanaman terutama N, P, dan K sehingga hasil pakchoi menjadi rendah. Pemberian pupuk kandang dapat berpengaruh baik terhadap penambahan unsur hara dalam tanah dan pertumbuhan tanaman karena dapat memenuhi unsur hara makro (N, P dan $\mathrm{K}$ ) dan unsur hara mikro yang diperlukan bagi pertumbuhan dan perkembangan tanaman yang akan diambil oleh tanaman dalam bentuk anion dan kation (Sutejo, 2002), selain itu juga dapat mengefisienkan dalam penggunaan dosis pupuk anorganik.

Tanah ini memiliki kandungan $\mathrm{N}$-total rendah (0,1\%), C-organik sangat rendah $(0,8 \%), \mathrm{C} / \mathrm{N}$ rendah (8), P-tersedia sedang $(10,3 \mathrm{mg} / \mathrm{kg}), \quad \mathrm{P}$ potensial sangat rendah $(16,7 \mathrm{mg} / 100 \mathrm{~g})$, nilai KTK sedang $(17,1 \mathrm{cmol} / \mathrm{kg})$, kejenuhan basa rendah (28,7\%), dan kejenuhan Al rendah (0,1\%). Hasil analisis fisika tanah menunjukkan tanah memiliki tekstur lempung liat berdebu, dengan kandungan pasir $13 \%$, debu $49 \%$ dan liat 38\%. Data tersebut menggambarkan kondisi tanah yang kandungan unsur haranya rendah sampai sedang, sedangkan untuk tumbuh dengan baik tanaman pakchoi menghendaki tanah yang subur, strukturnya gembur, kandungan bahan organik tinggi dan cukup unsur hara.

Pupuk kandang dalam percobaan ini memiliki nilai $\mathrm{pH}$ masing-masing, yaitu pupuk kandang ayam 7,42 dan pupuk kandang domba 7,73. Kandungan $\mathrm{N}$-total dari pupuk kandang ayam dan pupuk kandang domba masing-masing adalah 1,83\% dan 1,76\%. Kandungan C-organik dari kedua pupuk kandang ini juga tergolong tinggi yaitu masingmasing pupuk kandang ayam $24,83 \%$ dan pupuk kandang domba $29,72 \%$.

Hama yang ditemukan pada waktu percobaan yaitu belalang (Valanga sp.), aphid (Aphis gossypii) dan serangga ulat grayak (Spodoptera litura). Gejala yang terlihat berupa bekas gigitan belalang dan daun berlubang-lubang yang disebabkan oleh serangga ulat grayak. Penyakit yang terdapat pada tanaman pakchoi yaitu seluruh daunnya keriting. Hal ini diduga disebabkan oleh virus, karena menyerang seluruh daun pada tanaman pakchoi.

Pengamatan tinggi tanaman pakchoi dilakukan satu minggu sekali, pada 7 HST hingga 42 HST. Meskipun perlakuan 0,5 dosis pupuk anorganik dan pupuk kandang ayam $50 \mathrm{~g} /$ polibeg memberikan nilai tinggi tanaman pakchoi tertinggi akan tetapi tidak jauh berbeda dengan perlakuan yang lainnya, kecuali jika di bandingkan dengan perlakuan kontrol (Gambar 1). Pengamatan jumlah 
daun dilakukan bersamaan dengan pengamatan tinggi tanaman. Pertambahan jumlah daun secara visual terlihat pada saat tanaman pakchoi berumur 21, 28, 35, dan 42 HST (Gambar 2).

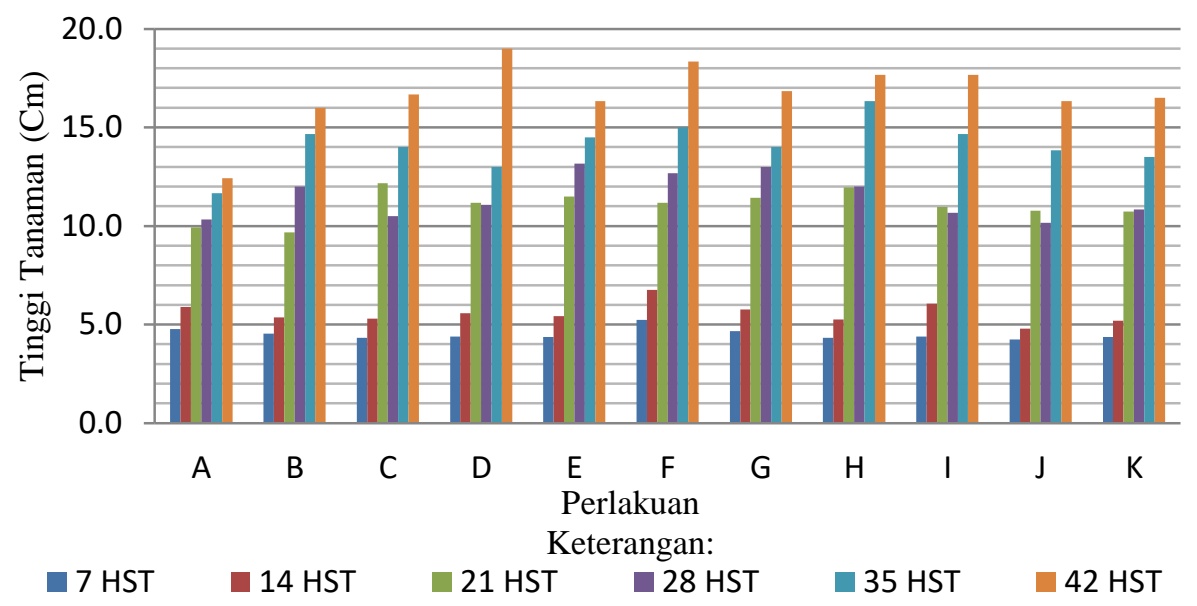

Gambar 1. Diagram pertumbuhan tinggi tanaman pada berbagai perlakuan dan hari setelah tanam

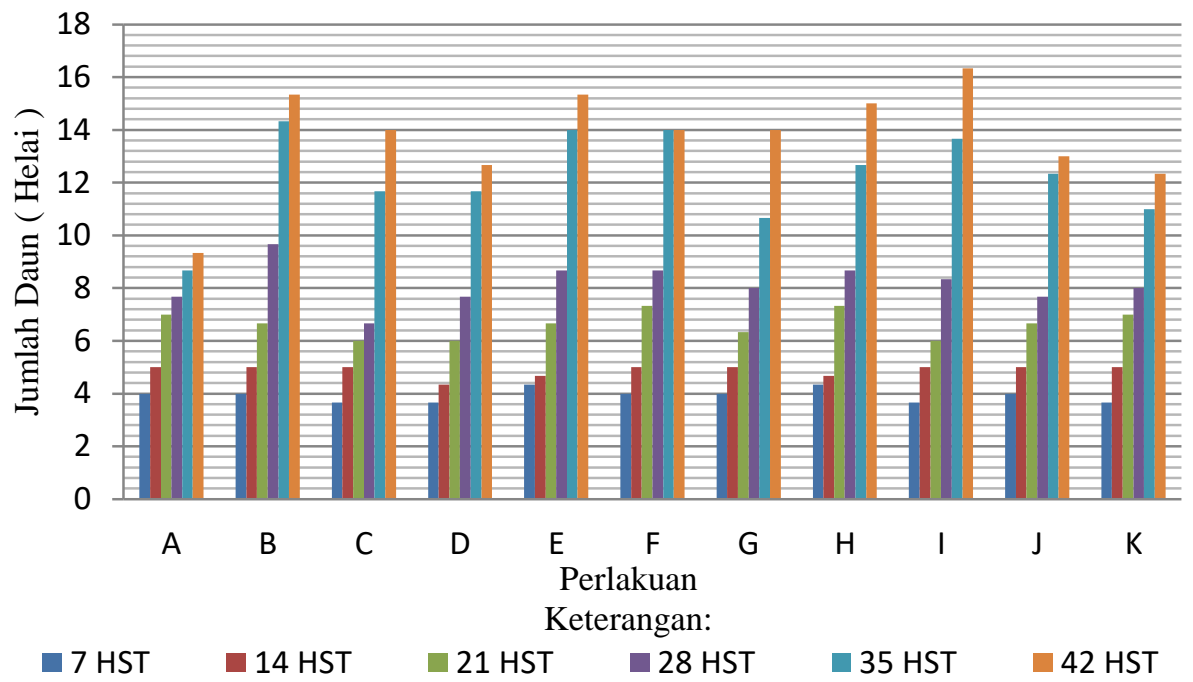

Gambar 2. Diagram jumlah daun tanaman pada berbagai perlakuan dan hari setelah tanam

Suhu rata-rata rumah kaca pada pagi hari adalah $29,30^{\circ} \mathrm{C}$, dan $260^{\circ} \mathrm{C}$ pada sore hari. Hasil pengamatan suhu rata-rata harian rumah kaca pada bulan Mei adalah $27,60^{\circ} \mathrm{C}$, dan $27,50^{\circ} \mathrm{C}$ pada bulan Juni. Suhu optimum untuk pertumbuhan tanaman pakchoi adalah $220^{\circ} \mathrm{C}$ sampai $320^{\circ} \mathrm{C}$ (Rahardi \& Wahyuni, 1993).

\section{SIMPULAN DAN SARAN}

\section{Simpulan}

Pemberian kombinasi jenis dan dosis pupuk kandang berpengaruh terhadap peningkatan $\mathrm{pH}, \mathrm{N}-$ total, serapan-N dan hasil tanaman pakchoi. Pemberian pupuk kandang domba 75 g/polibeg dapat meningkatkan nilai $\mathrm{pH}$ terbaik menjadi 6,23 dibandingkan dengan perlakuan lainnya. Pemberian kombinasi pupuk kandang pada 0,25 dosis pupuk anorganik dengan pupuk kandang ayam 62,5 g/polibeg dapat meningkatkan $\mathrm{N}$-total terbaik menjadi 0,29\%, serapan-N menjadi 38,98 g dan meningkatkan hasil bobot segar tanaman pakchoi menjadi 76,77 g/tanaman dibandingkan dengan perlakuan lainnya.

\section{Saran}

Penelitian lanjutan perlu dilakukan terutama aplikasinya di lapangan dengan perlakuan kombinasi jenis dan dosis pupuk kandang yang sama, sehingga kombinasi jenis dan dosis pupuk kandang benarbenar dapat 
dijadikan alternatif dalam pemupukan untuk menuju sistem pertanian organik yang ekonomis dan efisien serta ramah lingkungan.

\section{DAFTAR PUSTAKA}

Atmojo, SW. 2007. Pertanian Organik, Integrasi Ternak dan Tanaman. Solo Pos. 7 Maret 2007.

Badan Penelitian dan Pengembangan Pertanian. 2002. Prospek Pertanian Organik di Indonesia. Balai Pengkajian Teknologi Pertanian Jawa Tengah. Agro Inovasi. Tersedia online pada http://www.litbang.deptan.go.id/berita/on e/17/. (Diakses 24 Januari 2010).

Balai Penelitian Tanah. 2005. Pupuk Organik Tingkatan Produksi Pertanian. Agro Inovasi, Bogor. Tersedia online pada http://www.pustakadeptan.go.id/publikasi/wr (Diakses 24 Januari 2010).

2760.pdf. en Pertanian. 2009. Basisdata Statistik Pertanian. Sinar Tani. Tersedia online pada

http://www.deptan.go.id/tampil.php?page =inf_basisdata. (Diakses 16 September 2010).

Hakim. 1986. Dasar-dasar Ilmu Tanah. Cetakan Pertama. Universitas Lampung, Lampung.

Hardjowigeno, S. 2007. Ilmu tanah. Akademika Pressindo, Jakarta.

Musnamar, EI. 2003. Pupuk Organik. Penerbit Penebar Swadaya, Jakarta.

Napitupulu, D, dan L Wiranto. 2010. Pengaruh pemberian pupu $\mathrm{N}$ dan $\mathrm{K}$ terhadap pertumbuhan dan produksi bawang merah. J. Hort. 20(1): 27-35.
Pavlou GC, CD Ehaliotis, and VA Kavvadias. 2007. Effect of organic and inorganic fertilizers applied during successive crop seasons on growth and nitrate accumulation in lettuce. Scientia Horticulturae. 111(4): 319-325.

Rahardi, F, dan S Wahyuni. 1993. Agribisnis Tanaman Sayur. Penebar Swadaya, Jakarta.

Sarief, S. 1989. Kesuburan dan Pemupukan Tanah Pertanian. Pustaka Buana, Bandung.

Soepardi, G. 1983. Sifat dan Ciri Tanah. Jurusan Ilmu Tanah Fakultas Pertanian IPB, Bogor.

Sudirja, R, MA Solihin, dan S Rosniawaty. 2007. Respons beberapa sifat kimia fluventic eutrudepts melalui pendayagunaan limbah kakao dan berbagai jenis pupuk organik. Soilrens 8(16): 849-858.

Sutejo, M. 2002. Pupuk dan Cara Pemupukan. Rineka Cipta, Jakarta.

Syafruddin, Nurhayati, dan R Wati. 2012. Pengaruh jenis pupuk terhadap pertumbuhan dan hasil beberapa varietas jagung manis. J. Floratek. 7: 107-114.

Syukur, A. 2008. Pengaruh Pemberian Pupuk Kandang dan NPK terhadap Beberapa Sifat Kimia dan Fisika Tanah Pasir Pantai Samas Bantul. Fakultas Pertanian UGM, Yogyakarta. Tersedia online pada http://soil.faperta.ugm.ac.id/jitl/pdf. (Diakses 19 Agustus 2010).

Tisdale, SW, JL Nelson, JL Halvin, and JD Beaton. 1993. Soil Fertility and Fertilizer. Sixth Edition. Prentice Hall, New Jersey.

Wahyudi. 2010. Petunjuk Praktis Bertanam Sayuran. PT Agromedia Pustaka, Jakarta.

Winarso, S. 2005. Kesuburan Tanah, Dasar Kesehatan dan Kualitas Tanah. Gaya Media, Yogyakarta. 